\title{
The Recent Reform of Spanish Local Governmental Accounting: A Critical Perspective from Local Governmental Accountants as Internal Users of Budgeting and Financial Accounting Information
}

\author{
Rosa MARÍA Dasí-GonZÁlez, AMPARO GiMENO-RuÍz \& José MANUEl VELA- \\ BARGUES
}

\begin{abstract}
Local Government Accounting and Financial Reporting in Spain has been recently reformed by the new Accounting Instructions published in 2103 and in force since the $1^{\text {st }}$ of January 2015. Once the financial reports corresponding to 2016 fiscal year have been published, the main purpose of this paper is to empirically evaluate, the perceptions and opinions that local governmental accountants have about the recent reform. Our analysis has found a clear gap between the aims of the reform and the opinion of local governmental accountants, who consider the system too complex and clearly biased towards financial accounting information.
\end{abstract}

Keywords: - usefulness of accounting information - budgetary accounting • accrual accounting • local government accountants • local government $\bullet$ Spain

Correspondence AdDress: Rosa María Dasí-González, Ph.D., Lecturer. Universitat de València, Facultat d'Econmia, Av. Tarongers s/n. 46022 Valencia, Spain, email: rosa.m.dasi@uv.es. Amparo Gimeno-Ruíz, Ph.D., Lecturer, Universitat de València, Facultat d'Econmia, Av. Tarongers s/n. 46022 Valencia, Spain, email: amparo.gimeno@uv.es. José Manuel Vela-Bargues, Ph.D., Professor, Universitat Politèncica de València. Camino de Vera s/n, 46022 Valencia, Spain, email: jovebar@upv.es.

https://doi.org/10.4335/16.3.453-476(2018)

ISSN 1581-5374 Print/1855-363X Online (C) 2018 Lex localis

Available online at http://journal.lex-localis.press. 
LEX LOCALIS - JOURNAL OF LOCAL SELF-GOVERNMENT

R. M. Dasí-González, A.Gimeno-Ruíz \& J. M.Vela-Bargues: The Recent Reform of Spanish Local Governmental Accounting: A Critical Perspective from Local Governmental Accountants as Internal Users of Budgeting and Financial Accounting Information

\section{$1 \quad$ Introduction}

In 2016, local governments in Spain published for the first time its financial reports prepared using the new accounting standards introduced by the last reform that started in 2013, with the publication of two Ministry of Economy and Finance orders that developed new accounting rules concerning the normal and simplified models for local government financial reporting, reforming also the basic model for small municipalities. These new rules, which are in force since the 1st of January 2015, develop the accounting and financial reporting standards that Spanish municipalities must apply since this date.

The main purpose of this paper is to empirically evaluate, through a questionnaire addressed to small, medium and big size municipalities, the local governmental accountants' opinions about the recent reform and their assessments about it. The results obtained show accountants' critical perception of the reform.

Considering this purpose, the paper is structured as follows. In section 2 we present the analysis of the main guidelines and developments of the 2015 accounting and financial reporting reform, pointing out the main changes introduced by the new accounting Instructions.

The third section focuses on identifying some key questions concerning the reform that, according to the authors, must be considered in order to understand the real scope of the reform and that are basically related to the questions that are included in the survey. These questions are connected to the complexity of the accounting system, the way financial accounting and budget execution information are articulated in a single system, the usefulness of both types of information, the role of auditing and consolidated financial reports, the development of cost accounting and the information concerning the accomplishment of the budgetary stability goals fixed by the Central Government.

In section 4 we present the sample and methodology and, in section 5, we summarized the findings. Finally, we draw some conclusions.

2 Local governmental accounting: Main guidelines of the 2015 reform
and changes introduced

Even if the present situation of local governmental accounting in Spain is the result of this last reform, two previous reforms must also be considered to understand the present "state of the art" of the Spanish local financial reporting system. 
R. M. Dasí-González, A.Gimeno-Ruíz \& J. M.Vela-Bargues: The Recent Reform of Spanish Local Governmental Accounting: A Critical Perspective from Local Governmental Accountants as Internal Users of Budgeting and Financial Accounting Information

The first reform, and perhaps the most important one was introduced in 1992. The application of a new accounting system was achieved through the introduction of two models: the so-called "standard model" and the "simplified model", regulated in the orders of the Ministry of Economy and Finance, approved on July 17, 1990. The simplified model established a special and summarized accounting system for municipalities with a population of less than 5.000 inhabitants. Each of these two accounting instructions incorporated, in an annex, the Accounting Plan (Chart of Accounts) applicable for entities that are subject to the model in question, "normal" or "simplified". In both cases this Plan was an adaptation of the version of the 1983 Plan adopted at central government level, and introduced for the first time at local level accrual accounting for financial accounting, the double entry system of bookkeeping and the articulation of budgetary and financial accounting information in a unique system (Vela, 1996).

The approval in 1994, by the order of May 6, of the Ministry of Economy and Finance, of a new General Accounting Plan for central government public that came to replace the previous 1983 version, compelled again to reform local governmental accounting, adapting its accounting regulations to this Plan.

This reform, which took place in the 2004, was articulated through three accounting models that came to replace the two that existed previously, and set its effective implementation for the financial year 2006. These models were regulated in three basic instructions:

1. Instruction for local governmental accounting (normal model), approved by order EHA/4041/2004 of 23 November.

2. Instruction of local governmental accounting (simplified model), approved by order EHA/4042/2004 of 23 November.

3. Instruction of local governmental accounting (basic model), approved by order EHA/4040/2004 of 23 November. For small municipalities, using a single entry system of book-keeping.

The scope of the three models differed depending on the size of local authorities according to two variables: population and the amount of its budget, and not only on the population as traditionally. Like in the case of the 1990 Instructions, the new instructions for the "normal" and the "simplified" models incorporated, as an annex, an Accounting Plan adapted to the 1994 General Accounting Plan for Central Government

The adoption of a new General Accounting Plan in 2010, approved by order EHA/1037/April 13, 2010, once again, allowed to anticipate a new reform of local governmental accounting. 
R. M. Dasí-González, A.Gimeno-Ruíz \& J. M.Vela-Bargues: The Recent Reform of Spanish Local Governmental Accounting: A Critical Perspective from Local Governmental Accountants as Internal Users of Budgeting and Financial Accounting Information

This reform started in 2013 and has resulted in a revision of the accounting regulations of implementation with local authorities and their autonomous entities, distinguishing again a normal, a basic and a simplified model. With this purpose, two new ministerial orders introducing new accounting standards were approved:

1. Order HAP/1781/2013, September 20, which approves the normal model accounting Instruction.

2. Order HAP/1782/2013 September 20, which approves the simplified model accounting Instruction and modifies the basic model Instruction approved by order EHA/4040/2004 of 23 November. This basic model is based only on budgetary information (Brusca et al., 2015)

Like it occurred with the 2010 reform of the General Accounting Plan at central government level, the 2015 reform of local governmental accounting introduced as main changes the following:

a) For the first time, the first part of the local General Accounting Plan is dedicated to define a conceptual framework for local authorities accounting system.

b) The new Local General Accounting Plan is adapted to international public sector accounting standards, supporting the introduction of the fair value as a valuation criterion.

c) The accounting principles that were previously developed in a single part of the General Accounting Plant are now dealt within its first part devoted to the conceptual framework. The purchase price is no longer considered as an accounting principle and becomes an additional rule included with the rest of valuation criteria. The traditional principle defined as "matching concept" referred to revenue and expenses registration is now considered among the rest of possible recognition criteria for the elements of the annual accounts. Finally, the principle of Accounting Entity is now included in the definition of the "true and fair view concept".

d) The new Local Accounting Plan introduces new accounting criteria for the recognition of non-financial fixed assets, infrastructures, military investments and heritage; real estate investments and selling public assets.

e) The accounting treatment of financial assets and liabilities is also modified.

f) The standard registration and assessment no.18 "Transfers and subsidies" presents important developments, mainly regarding the accounting allocation transfers and subsidies received, distinguishing between refundable and nonrefundable (Dasí \& Gimeno, 2014).

g) The new Local Accounting Plan has also increased the number of financial statements to be included in the annual accounts, the main novelty being the 
R. M. Dasí-González, A.Gimeno-Ruíz \& J. M.Vela-Bargues: The Recent Reform of Spanish Local Governmental Accounting: A Critical Perspective from Local Governmental Accountants as Internal Users of Budgeting and Financial Accounting Information

addition of two new ones: the statement of changes in equity and the cash flow statement.

h) As notes to financial statements (memory statement), information about costs by activities and budget, financial and management indicators have been included for the first time.

i) The statements on accounting principles (Documentos sobre Principios Contables) approved by the Committee on principles and public accounting standards, which constituted the conceptual framework for the 1994 General Accounting Plan (Montesinos \& Vela, 2003), can still be applied when no conflict exists with the provisions of The Local Accounting Plan now in force since the first of January 2015.

j) Finally, the accounts developed for the registration of the budget execution process on Group of Accounts 0 are not compulsory anymore, even if for practical reasons its use continues to be very extended.

The aforementioned changes have been introduced due to two main purposes:

- The need to harmonize reporting systems and accounting standards at local and central government levels. This is why the General Accounting Plan for local authorities has been adapted to the 2010 Plan for Central Government

- The need to eliminate the regulations contained in the previous accounting local instructions at local levels that are now developed by the general accounting plan for local governments.

The main guidelines followed by 2015 reform continue the same itinerary that has characterised the recent evolution of governmental accounting in Spain (Vela, 2015), with the exception of the third one that is clearly new and has to be therefore considered for the first time. Those guidelines are the following:

1. The high level of harmonization of the accounting principles and standards among the different levels of government (central local and regional).

2. The strong influence of business accounting on governmental accounting.

3. The harmonization of the standards developed by the General Accounting Plan with the International Public-Sector Accounting Standards.

In Spain, the General Accounting Plan for Central Governmental entities has always followed as a model a General Accounting Plan previously introduced for business entities. It occurred in with the Central Governmental Accounting Plan approved in 1983 (based on the 1973 Business General Accounting Plan) and with the 1994 Governmental Accounting Plan, based in that case in the 1990 Business Accounting Plan.

The influence of business accounting has also prevailed in the last reform of Spanish central governmental accounting and consequently also at the local level. And the 
R. M. Dasí-González, A.Gimeno-Ruíz \& J. M.Vela-Bargues: The Recent Reform of Spanish Local Governmental Accounting: A Critical Perspective from Local Governmental Accountants as Internal Users of Budgeting and Financial Accounting Information

fact is that this influence has traditionally been a strong stimulus for introducing accounting reforms in the public sector (Fuertes, I. \& Vela, 2000).

The last reform of Spanish business accounting started with the law 16/2007, 4th of July, for the reform and adaptation of the commercial law on accounting matters to the regulations of the European Union. This law modified the Code of Commerce and the revised text of the Law for Corporations and Limited Liability Companies to advance in the process of international convergence. This harmonization process meant a new reform of the accounting basic legislation, culminating in the adoption of a new chart of accounts. This Plan was approved by Royal Decree 1514/2007 of 16 November, accompanied by another new plan: Accounting Plan for small and medium-size enterprises, approved by Royal Decree 1515/2007 of 16 November. Both plans entered into force on the 1st January 2008. As a consequence of those Plans, the 2010 General Accounting Plan for central government entities was introduced. This Plan, as we saw before, also inspired the 2013 General Accounting Plan for local government entities.

The second guideline that has inspired the last reforms has been again, as in previous ones, to reach a strong degree of harmonization of the accounting criteria applied by the different levels of administration (central, local and regional). The fact is that Spain has always followed an up-down model in the process of setting accounting standards, shifting reforms previously introduced at Central Government Level to lower levels of government.

The third guideline that has inspired the last reform is clearly new: the clear commitment in the 2010 General Accounting Plan for governmental entities, and consequently in the 2013 local Plan, to adapt its accounting standards to Public Sector International Accounting Standards issued by the International Public Sector Accounting Standards Board (IPSASB). This fact is of special relevance, considering that no EU standard establishes the requirement to do so for governmental entities.

\section{Some key questions about the 2015 reform}

After analyzing the recent developments of local governmental accounting in Spain, we proceed now to present several key questions that usually arise in academic and professional debates concerning governmental accounting at local level.

For a better understanding of these key questions, it is important to note that, in Spain, local governmental accounting standards are set by central government through the Ministry of Public Finance, and not by accounting professionals. Accounting professionals participate in the process of issuing accounting standards 
R. M. Dasí-González, A.Gimeno-Ruíz \& J. M.Vela-Bargues: The Recent Reform of Spanish Local Governmental Accounting: A Critical Perspective from Local Governmental Accountants as Internal Users of Budgeting and Financial Accounting Information

and can propose amendments to the published exposure drafts of future regulations in their preparation phase, but the final decisions are adopted by Government by laws, decrees or ministerial orders. In that sense, the situation is quite different than in Anglo-Saxon countries were private professional institutions are more active, in the regulation process.

In this context, the debate we consider worth to develop around the recent reform of local governmental accounting is related to the following key questions:

1. The flexibility and complexity of the accounting system

2. The relationship between budgetary and financial accounting information.

3. The scope and content of financial standardized reports (annual accounts).

4. Cost Accounting.

5. Consolidated annual accounts.

6. The reporting of accounting information related to national accounting figures

7. The external auditing of annual accounts.

As we have pointed out previously, all the reforms introduced in Spanish governmental accounting have established different models of financial reports depending on the size of municipalities. The existence of different models aims to introduce a reasonable degree of flexibility to reduce the complexity of the accounting system. With respect to the 2015 reform, the size of municipalities is fixed according to two main variables that allow to distinguish three main reporting models: simplified, basic, and normal. Those variables are the population and the global amount of budget referred to the fiscal year.

As shown in Table 1, the limits fixed to determine the model that has to be adopted by a single municipality are the following:

Table 1: The three different reporting models

\begin{tabular}{|c|c|c|}
\cline { 2 - 3 } \multicolumn{1}{c|}{} & \multicolumn{2}{c|}{ POPULATION } \\
\hline BUDGET & $\leq 5.000$ inhabs. & $>5.000$ inhabs. \\
\hline$<300.000 €$ & BASIC & BASIC \\
\hline $300.000-3.000 .000 €$ & SIMPLIFIED & NORMAL \\
\hline$>3.000 .000 €$ & NORMAL & NORMAL \\
\hline
\end{tabular}

In our opinion, the introduction of different models has not been fairly effective in order to avoid complexity, given that a great number of medium sized municipalities have to adopt the normal model, with a level of reporting disclosure and compulsory accounting standards very similar to those that central government has to apply, despite its size being not comparable with a municipality. As we will see later, the 
R. M. Dasí-González, A.Gimeno-Ruíz \& J. M.Vela-Bargues: The Recent Reform of Spanish Local Governmental Accounting: A Critical Perspective from Local Governmental Accountants as Internal Users of Budgeting and Financial Accounting Information

survey developed evidences that the complexity of the accounting system is one of the main critical opinions that local governmental accountants express concerning the last accounting reform, whose flexibility goals seem rather unsuccessful after its first year of implementation.

The relationship between budgetary and financial accounting information in Spanish governmental accounting systems, at all levels of government, has always been developed through the combination of both types of information in a unique accounting and reporting system.

The question remains if the volume and level of disclosure required for budget and financial accounting information is appropriate to the real information needs of the different types of internal and external users. Some groups of users such as politicians, journalists or local taxpayers have traditionally criticized the complexity of the accounting system, especially considering that the level of information required concerned with financial accounting information is too high considering its further use for their decision-opinion making process, basically based in information related to the budget. If we consider other users such as financial directors, the situation is very similar, especially considering that "after two decades of reforms in financial and management systems, financial directors still consider that budgetary reporting is the most useful, basically because the control of expenditure is still based on the budget" (Brusca \& Montesinos, 2013).

The fact is that in the social and political environment of Spanish governmental accounting the extended use of budgetary information strongly prevails among accounting information users, which have generally evidenced a clearly trending culture of superiority of budget with respect to financial accounting. As we will see later with our survey, the results obtained are quite clear, emphatic and categorical.

The scope and content of financial standardized reports (annual accounts) at the local level is another key question worth to analyze, especially considering that local financial and budgetary reports, according to the existing standards, have been strongly influenced by the content and structure they adopt in the case of business accounting.

After the 2015 reform, Spanish local authorities present the following annual reports:

- Balance Sheet.

- Operative statement.

- Statement of changes on net assets.

- Cash Flow Statements.

- Budget Execution Statement. 
R. M. Dasí-González, A.Gimeno-Ruíz \& J. M.Vela-Bargues: The Recent Reform of Spanish Local Governmental Accounting: A Critical Perspective from Local Governmental Accountants as Internal Users of Budgeting and Financial Accounting Information

- Notes to Financial Statements.

An interesting debate can be raised regarding the usefulness of those reports for accounting information users, especially considering that most users emphasize the use of Budget Execution Statements with respect to the rest (Vela, 2015). Local governmental accountants evidence a significant consensus around some issues: the need to present a statement of changes on net assets and the importance of a statement included as a note to financial statements that perhaps should be considered as an additional annual account to evaluate properly the financial position of a given municipality: the cash surplus statement. This statement discloses a cash surplus calculated as the difference between non-collected receivables plus cash and unpaid expenditures.

The development of cost accounting and the reporting of consolidated annual accounts are two additional key questions that the 2015 reform has raised.

In respect of cost accounting, local entities with a population of more than 50.000 inhabitants are now requested to present, for fiscal years starting after the first of January 2017 additional information included as notes to financial statements, related to activities cost and performance indicators. The activities considered are those financed with fees or public prices.

The reporting of consolidation statements has been a very seldom-adopted practice in Spanish municipalities. This is why the 2015 reform has considered it as compulsory in the same terms and requirements established for cost accounting information. Through our survey, we have also requested local government accountants' opinion about both issues.

The reporting of accounting information related to national accounting figures is an additional key question we have considered.

After the introduction of the 2/2012 Organical Law on Budget Stability and Financial Sustainability, Spanish local authorities have to present additional information to the Ministry of Economy and Finance related to budget stability goals, in order to present relevant and reliable information to allow the calculation of National Accounting figures according to the European national accounts system (SEC) requirements. This Law has introduced a wide set of information requirements on budget stability that municipalities have to respect, as well as preventive and disciplinary provisions.

Once the Ministry of Economy and Finance has processed the information and national accounting figures for local government level have been calculated, we 
R. M. Dasí-González, A.Gimeno-Ruíz \& J. M.Vela-Bargues: The Recent Reform of Spanish Local Governmental Accounting: A Critical Perspective from Local Governmental Accountants as Internal Users of Budgeting and Financial Accounting Information

consider it would be useful to include some notes to financial statements reporting the results obtained by municipalities, in National Accounting terms, specially concerning debt and deficit figures. Even if this information is available for citizens in Ministry of Economy and Finance statistical base, in our survey, we have also requested local government accountants' opinion in that sense.

Finally, the last key question considered is concerned with the external auditing of local authorities' annual accounts.

In Spain, medium-sized and large companies according to the amount of assets and net sales, as well as number of employees, have to present every year an audit report prepared by an external and professional auditor. In this report, the auditor expresses his opinion in terms of the true and fair view reported in the audited accounts.

For local authorities, the situation is quite different, because legislation obliges them to report its accounts to the national and regional Courts of Accounts (audit commissions). But no systematic external audit requirements are legally established.

The present situation evidences that a vast majority of local authorities are not yearly audited, unless a Court of Accounts decides to include the full audit of a given municipality on its approved annual plan of audit. As the Courts of Accounts have limited human resources to establish regular external audits, the result is that a great number of municipalities, even big sized, don't undergo any external audit yearly. This is also due to the fact that Spanish legislation does not allow external audits for municipalities to be carried out by private auditors or audit firms.

If the external audit of local authorities is not established by law, the internal audit requirements are quite strong. But this fact does not justify the lack of external audits that are an overwhelming claim among the accounting profession and academic community.

Unfortunately, the 2015 reform has not introduced any advance in that field. Our survey has also requested local government accountants' additional opinions in that sense.

\section{$4 \quad$ Sample and methodology}

The sample was drawn from all Spanish municipalities with a population of at least 15,000 inhabitants, that usually present their annual accounts following the normal model defined in the new Accounting Instruction. During the months of January and February 2017 a questionnaire was sent to the Head Accountant of every 
R. M. Dasí-González, A.Gimeno-Ruíz \& J. M.Vela-Bargues: The Recent Reform of Spanish Local Governmental Accounting: A Critical Perspective from Local Governmental Accountants as Internal Users of Budgeting and Financial Accounting Information

municipality, a chartered civil servant, that has the responsibility of presenting annual accounts and implementing internal control programs.

The overall size of the sample is 553 municipalities although, in order to preserve the possible discriminating effect due to the size of the municipalities (Table 2), a stratified design was proposed in which three segments were distinguished.

Table 2: Sample size of the survey

\begin{tabular}{|c|c|c|}
\hline Strata & Inhabitants & Total municipalities \\
\hline 1 & +50.000 & 143 \\
\hline 2 & $50.00-25.000$ & 161 \\
\hline 3 & $25.000-15.000$ & 229 \\
\hline & TOTAL & 553 \\
\hline
\end{tabular}

In all three groups it was considered that not responding was non-significant, so that the three samples can be interpreted as a result of a random selection of the total municipalities of each segment.

The questionnaire was sent by e-mail to the Accountants of the selected municipalities, with a second reminder for those that did not respond on the first attempt. The questionnaire was composed of 18 questions in addition to three in order to characterize the statistical unit and the subject providing the answers. Depending on the interest of the measured variables, two scales have been established, one from 1 to 3 being 2 the neutral value and another from 1 to 5 in which 3 marks the neutral value.

A total of 104 municipalities have answered with the distribution shown in Table 3, which represents a response rate of $18.80 \%$. It is important to indicate that the nonresponse rate has been the same as in studies with similar characteristics, both in institutional scenarios and in business environments.

Table 3: Response level by size

\begin{tabular}{|l|c|c|}
\hline \multicolumn{1}{|c|}{ Inhabitants } & Total municipalities & Total answers \\
\hline More than 50.000 & 143 & 33 \\
\hline Between 50.00-25.000 & 161 & 33 \\
\hline Between 25.000-15.000 & 229 & 38 \\
\hline TOTAL & 553 & 104 \\
\hline
\end{tabular}

It is noteworthy that the level of response has been the same for all questions, in such a way that those who have answered the questionnaire have provided answers 
R. M. Dasí-González, A.Gimeno-Ruíz \& J. M.Vela-Bargues: The Recent Reform of Spanish Local Governmental Accounting: A Critical Perspective from Local Governmental Accountants as Internal Users of Budgeting and Financial Accounting Information

to all the questions asked. This indicates the high level of comprehension of the questions by the subjects and their optimal degree of involvement once they decided to accept their participation in the survey.

Two levels of analysis have been determined for all variables considered in the study:

- A first specific level within each segment that allows to establish comparisons between the results of each one.

- A second level in which the results are elevated to the whole global universe. The elevation factors associated to each municipality of the sample are equivalent to the number of municipalities of the total population they represent. This methodology is usually applied by the Spanish National Institute of Statistics in its studies of the active population.

In order to guarantee the validity of the elevation to the global universe, the specific results of each segment have been adequately weighted, so that possible deviations between the degrees of relevance of each segment have been corrected.

It is important to point out that these weighting/elevation factors would have been unnecessary if the degree of sample representation had been similar in all strata. We have processed the data employing the statistical software of SPSS, using as a weighting variable of the unit cases, the specific sample representation of each segment.

\section{$5 \quad$ Analysis of obtained results}

Considering the reporting requirements of the new Accounting Instructions, the first questions of the survey concerned the complexity of the accounting and reporting system. After the regulatory reform in Spain and taking into account its use for decision making, the information obtained from the public accounting information system is considered complex for 55,6\% of Accountants, and very complex for $43,6 \%$ of them. No significant differences exist among the three segments considered.

Regarding the usefulness of the information provided, practically all respondents consider budgetary accounting (using a modified cash basis) to be more useful than financial accounting (adopting an accrual basis) (Figure 1). It is remarkable the fact that on a scale of 1 to 5 , where 1 expresses no utility and 5 maximum utility, most of the accountants graded the budgetary reports with the maximum score and no respondent has scored it with a value less than 3 . No significant differences among the three groups of municipalities can be identified. Figure 1 establishes the detail of 
R. M. Dasí-González, A.Gimeno-Ruíz \& J. M.Vela-Bargues: The Recent Reform of Spanish Local Governmental Accounting: A Critical Perspective from Local Governmental Accountants as Internal Users of Budgeting and Financial Accounting Information

the results obtained considering local governments population, showing that the usefulness of financial reports is slightly higher in small municipalities.

Figure 1: Average level of usefulness of accounting information by population

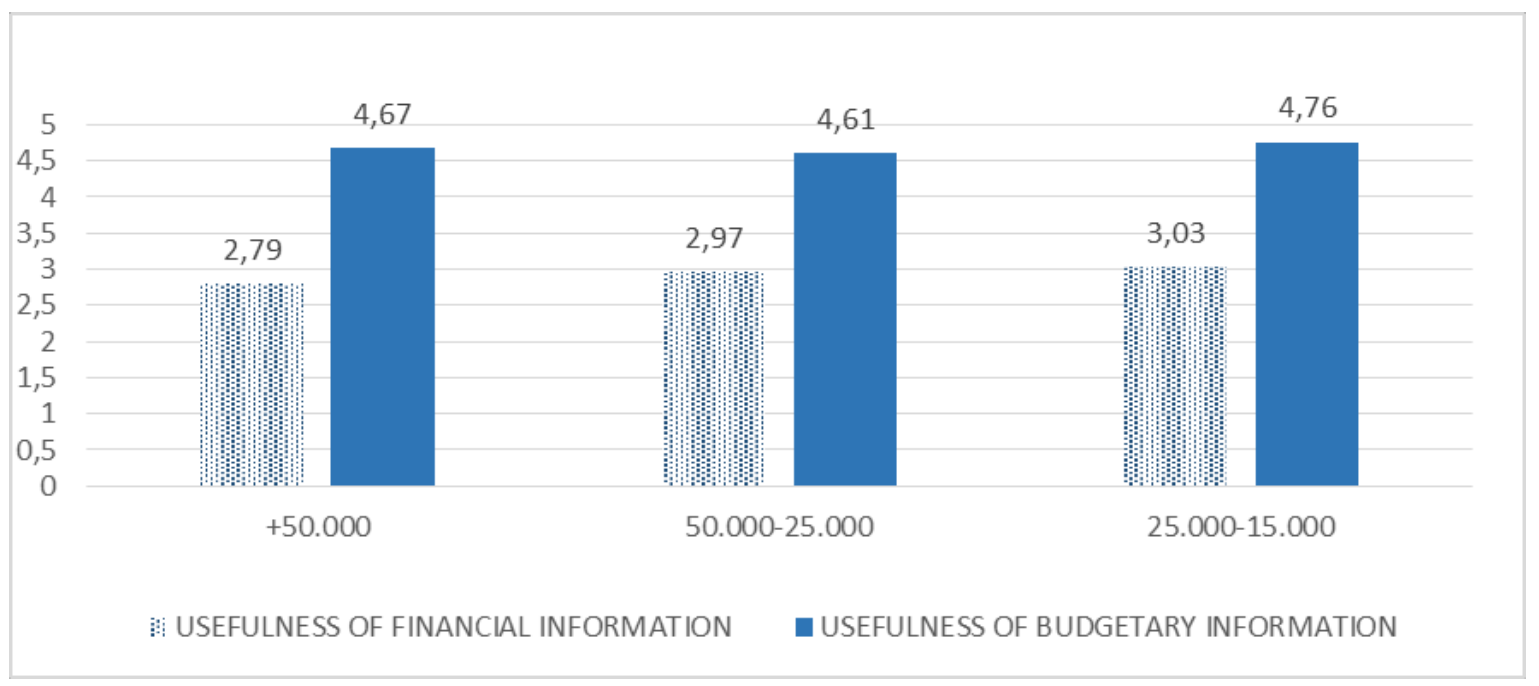

The greater usefulness of budgetary accounting for decision-making purposes rather than financial accounting has not changed in the last years, as pointed out by some studies at local and regional levels of public administration, (Montesinos et al., 2001); (Brusca \& Montesinos, 2013). As we highlighted before, the strong influence of business accounting in the design of the Spanish governmental accounting has always been very significant. However, the fact is that local governmental accountants implement the new standards just as a legal requirement, even when they do not appreciate their usefulness for public management. This is perhaps due to the fact that accrual accounting has been introduced in public entities adapting the accounting framework used by business entities, without considering the wide range of differences that exist between both types of organizations (Ellwood, 2001).

Local governmental accountants were also asked about the use that politicians make of the financial reports they prepare. The results obtained in that case are quite similar, as it is shown in figure 2. The local governmental accountants assume that politicians make decisions taking into account the budgetary information and do not pay attention to the financial information.

These results are consistent with the 2016 OECD Accruals Survey (OECD/IFAC, 2017). As OECD recognizes, policy-makers have limited interest in accrual information possibly due to the cash budget balance and net lending remaining the key targets. 
R. M. Dasí-González, A.Gimeno-Ruíz \& J. M.Vela-Bargues: The Recent Reform of Spanish Local Governmental Accounting: A Critical Perspective from Local Governmental Accountants as Internal Users of Budgeting and Financial Accounting Information

In this line, the dual systems implemented in European Continental countries do not require the introduction of deep organizational changes and answer the democratic demands of citizens for higher responsiveness, transparency and accountability, while traditional budgetary statements on the cash basis are maintained for monitoring compliance with legality and for administrative decision-making purposes (Pina et al., 2009)

Figure 2: Usefulness of accounting information for politicians by population

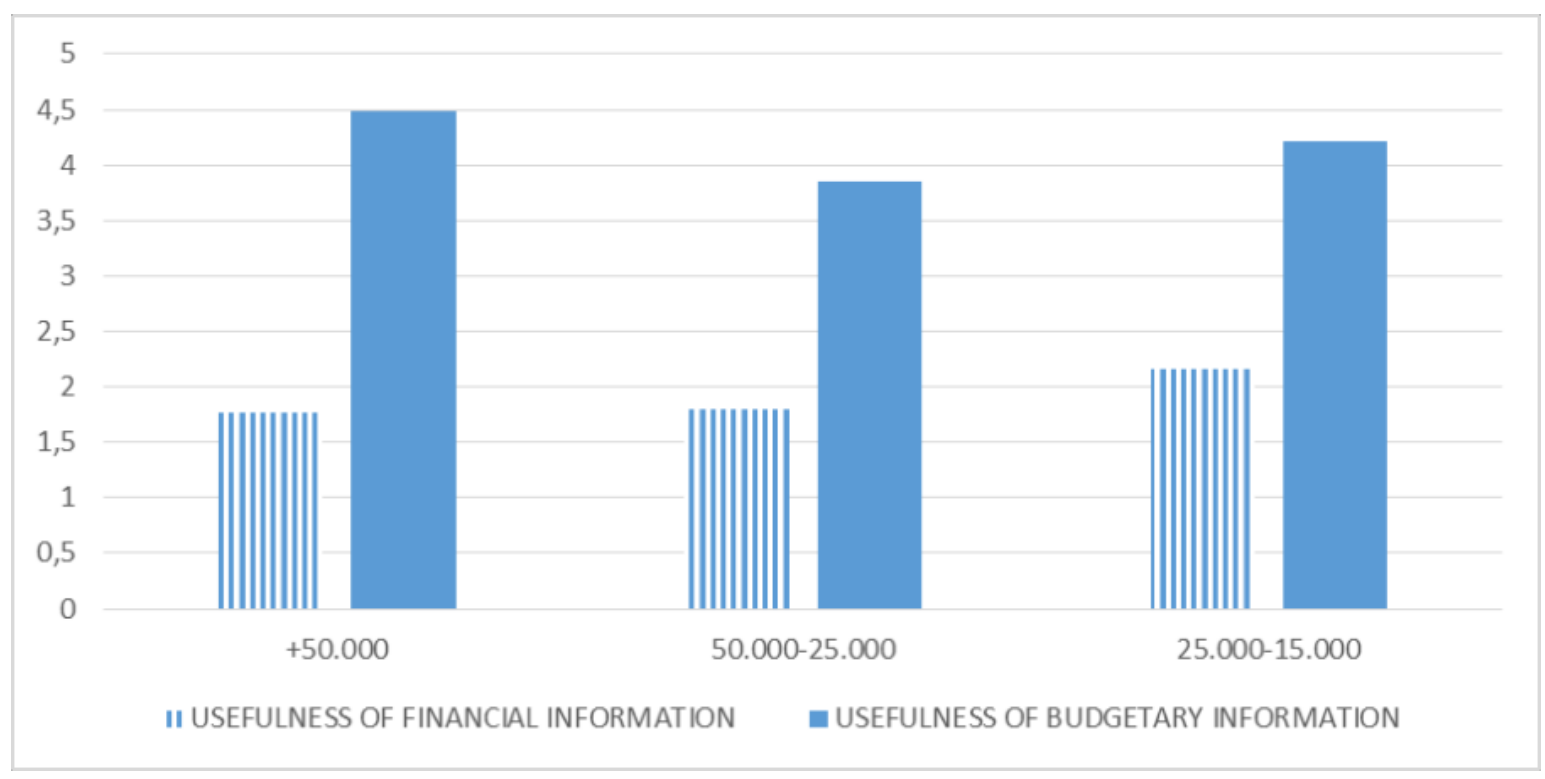

IFAC (2014) has highlighted the importance of financial statements for assessing financial sustainability, considering them vital to achieve an understanding of the present situation of public finances. Specifically, IFAC (2012) indicates that the income statement provides useful information for assessing future ability of governments to continue providing the same services while maintaining their quality, which is a main feature of long-term fiscal sustainability. IPSAS no 1 (IFAC 2014) indicates that the statement of financial performance, also named as income statement, reflects all items of revenue and expense recognized in the fiscal period. So, the income statement comprises positive components (revenues), which are added, and negative components (expenses), which are subtracted. The balance of this financial statement is obtained as a difference of these components, which are registered under accrual basis of accounting (called surplus/deficit of the period).

As mentioned in the second part of this paper, the annual accounts of municipalities include six main financial statements. As the complexity of the accounting system has been clearly recognized by local government accountants, they were also asked about the convenience of eliminating any of these statements. The majority of accountants $(69,4 \%)$ would eliminate some financial statement. Specifically, the less 
R. M. Dasí-González, A.Gimeno-Ruíz \& J. M.Vela-Bargues: The Recent Reform of Spanish Local Governmental Accounting: A Critical Perspective from Local Governmental Accountants as Internal Users of Budgeting and Financial Accounting Information

relevant financial statements are the cash flow statement and the changes in net position statement, as shown in figure 3 .

Figure 3: ¿Should any annual account be eliminated?

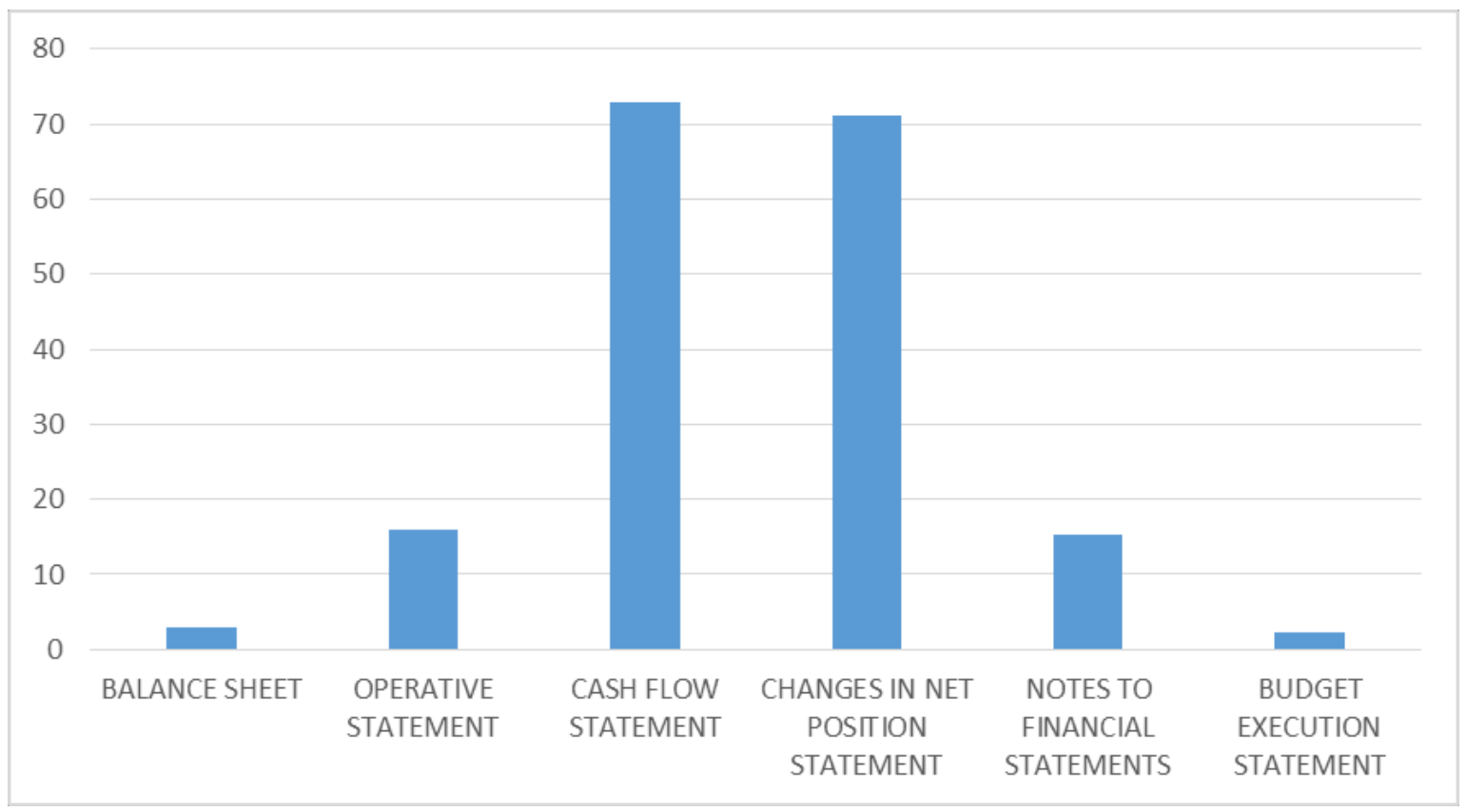

Regarding the cash flow statement, they consider, as we will see later, that the cash surplus statement is more relevant to assess a local government's financial position. Additionally, the lack of interest in the case of the statement of changes in net position can perhaps be explained by the stakeholders' absence of profit purpose. These results are consistent with 2016 OECD Accruals Survey (OECD/IFAC 2017) wherein it was found that fewer countries prepare a statement of cash-flow and changes in net assets, perhaps due to those being perceived as redundant when other cash reports are presented. On the other hand, it might also reflect a concern towards not overloading users with too many statements and, therefore, simplifying the presentation of the financial statements in the public sector.

The statements assessed as more useful are the balance sheet and especially the budget execution statement. This result is consistent with the findings obtained in respect of the usefulness of budgetary information.

The questionnaire also asked about the more relevant statements for appraising local governments' financial position. As we pointed out before the cash surplus statement is clearly the most useful for this purpose. The cash flow statement is also judged as a useful tool for this purpose, even when this statement would be eliminated by most of the accountants. On the contrary, as we can see in figure 4, the balance sheet is 
R. M. Dasí-González, A.Gimeno-Ruíz \& J. M.Vela-Bargues: The Recent Reform of Spanish Local Governmental Accounting: A Critical Perspective from Local Governmental Accountants as Internal Users of Budgeting and Financial Accounting Information

considered less useful for evaluating financial position. Non-significant differences exit when considering the three population segments (Figure 5). As we can appreciate again, the differences among the groups of population are not significant.

As Anessi-Pessina et al. (2010) pointed out, subnational governments' liquidity and solvency have two key determinants with do not show up in the balances sheet and operating statement: the ability to raise additional taxes and the likelihood of a bailout from upper tier of government. According to them, perhaps the existing accruals-based reports have not been adequately designed to capture the peculiarities of financial position in public sector organizations.

On the other hand, Navarro-Galera et al. (2016), have found empirically that the income statement supplies information about the capacity of the entities to continue providing goods and services in the same volume and quality and the level of resources that will be needed to provide them in the future, so this income statement is relevant to analyse the evolution of the intergenerational equity. Their results about revenues dimension imply that the revenues origin (external and internal) and its destination (operating and capital) can be specific factors which affect financial sustainability of local governments.

Figure 4: Relevant statements to evaluate financial position

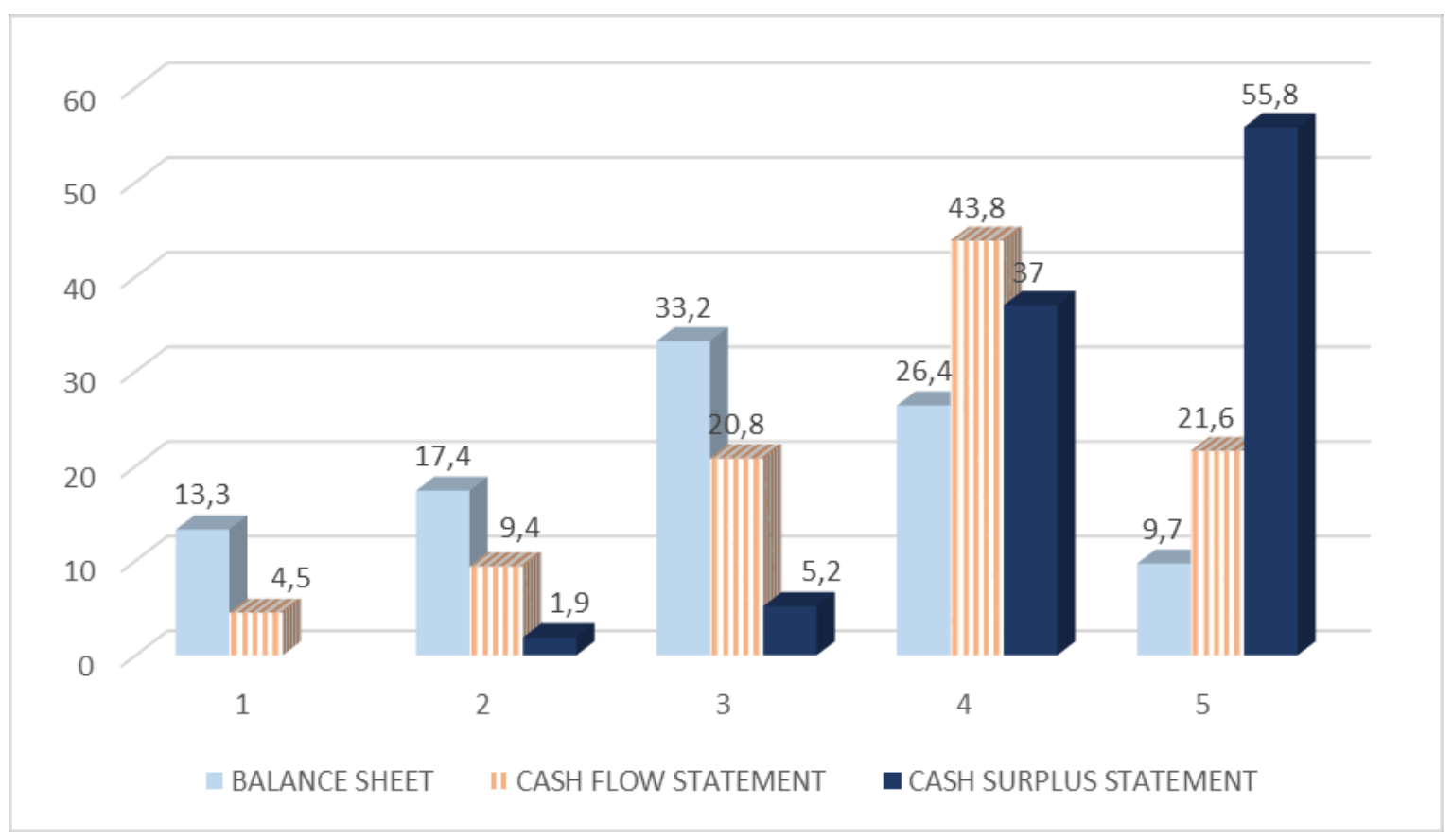

Figure 5: Mean value of relevance according to population size 
R. M. Dasí-González, A.Gimeno-Ruíz \& J. M.Vela-Bargues: The Recent Reform of Spanish Local Governmental Accounting: A Critical Perspective from Local Governmental Accountants as Internal Users of Budgeting and Financial Accounting Information

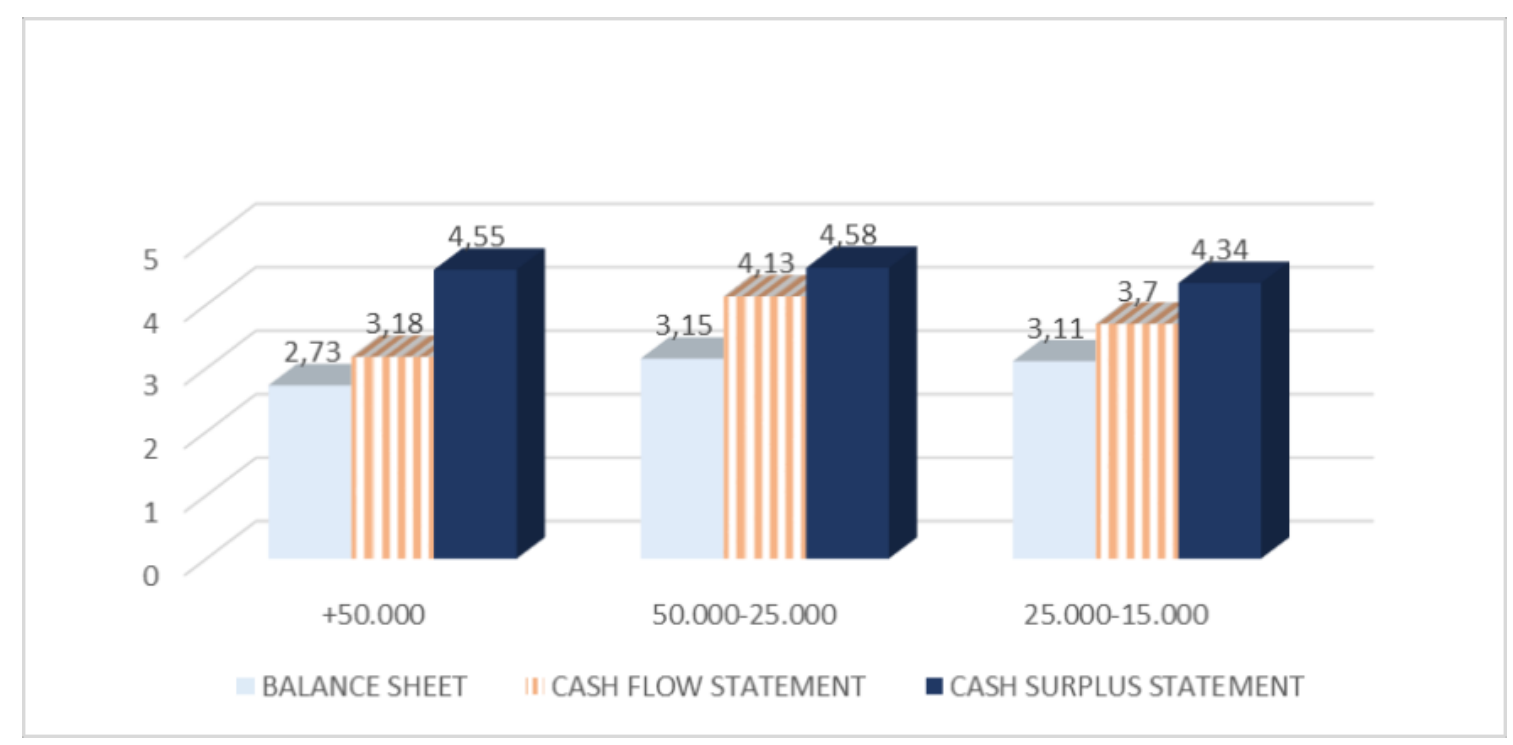

The results reinforce the wider debate on accrual accounting in the public sector, which, according with Arnaboldi \& Lapsley (2009), highlights the difficulties with the adoption of accrual accounting generally. The authors pointed out that, the specific context of local authorities offers distinctive challenges, given the historical accounting practices and the complexity of local authority activities.

Our questionnaire also analyses the convenience to include, as notes to financial statements, additional information that has not been considered as relevant in the last reform. This additional information refers to the following items:

- National Accounting figures (Debt and Deficit)

- Suppliers average term of payment

- Financial plans to reach budgetary equilibrium and their degree of accomplishment.

- Reconciliation between budgetary and operative result.

As we can see in figure 6, data related to payment terms and financial plans for budget equilibrium are appraised as the most relevant issues, while information on national accounting figures and the reconciliation of budget and operative results are considered less relevant. No significant differences appear relating to the population of municipalities. 
R. M. Dasí-González, A.Gimeno-Ruíz \& J. M.Vela-Bargues: The Recent Reform of Spanish Local Governmental Accounting: A Critical Perspective from Local Governmental Accountants as Internal Users of Budgeting and Financial Accounting Information

Figure 6: Additional Information to be included as notes to financial statements. Mean value by population

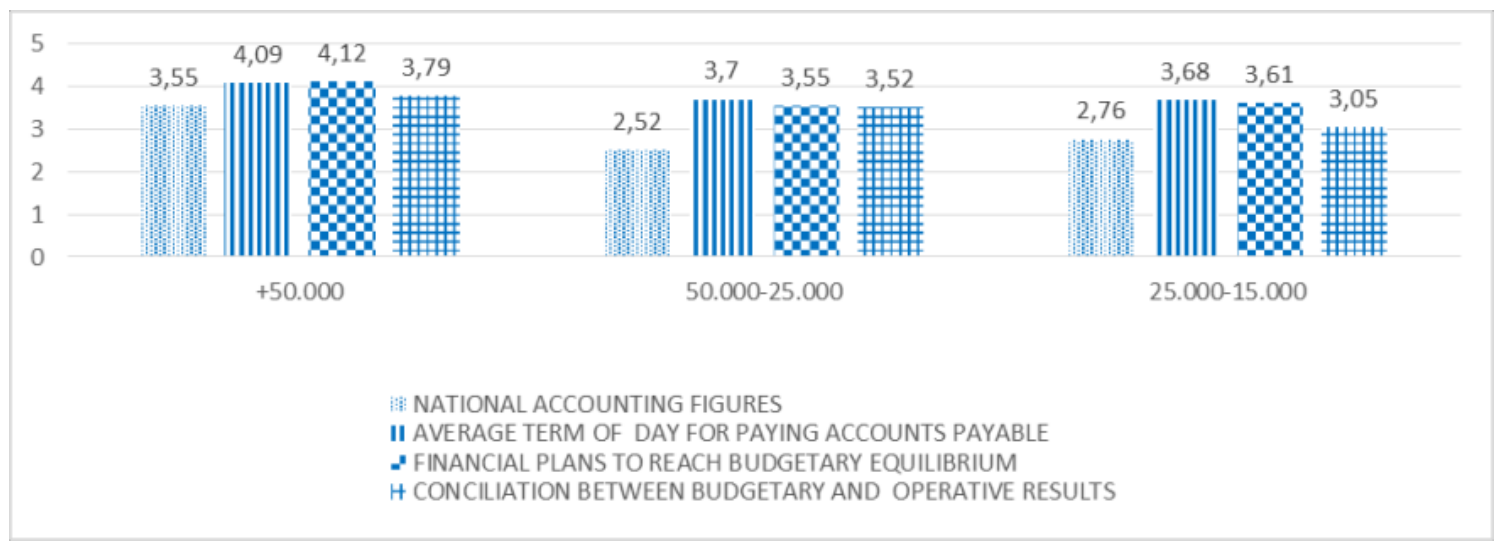

We have also requested the opinion of local government accountants about the requirement of consolidated financial statements, the development of cost accounting and the implementation of a yearly external audit as a compulsory requirement for municipalities reaching a certain size.

The growing development of municipal corporations has led to the fact that the annual reports of local governments disclose only a partial view of their economic and financial activities. This is because the financial consequences of subsidiaries, joint ventures and associates are not necessarily included in the annual reports of the local governments (Grossi and Tagesson, 2008); (Tagesson, 2009). For that reason, the development of consolidated financial statements in the public sector represent useful financial tools to improve transparency and accountability toward internal and external users (Montesinos \& Brusca, 2008; (Grossi et al., 2014).

As we pointed out in the second part of this paper, at this moment the presentation of consolidated financial statements is not an extended practice in Spanish local municipalities, even though it will be compulsory for municipalities of more than 5.000 inhabitants for fiscal years starting after the first of January 2017. However, local governmental accountants show no especial interest in the consolidated annual accounts because the average value obtained is close to 3 representing the neutral value on a scale of 1 to 5 (figure 7). This result can be understood in line with the assessment of Montesinos \& Brusca (2008) that the preparation of consolidated financial statements is a very difficult task, which may need a long time. 
R. M. Dasí-González, A.Gimeno-Ruíz \& J. M.Vela-Bargues: The Recent Reform of Spanish Local Governmental Accounting: A Critical Perspective from Local Governmental Accountants as Internal Users of Budgeting and Financial Accounting Information

Figure 7: Average value of usefulness of consolidated financial statements by population

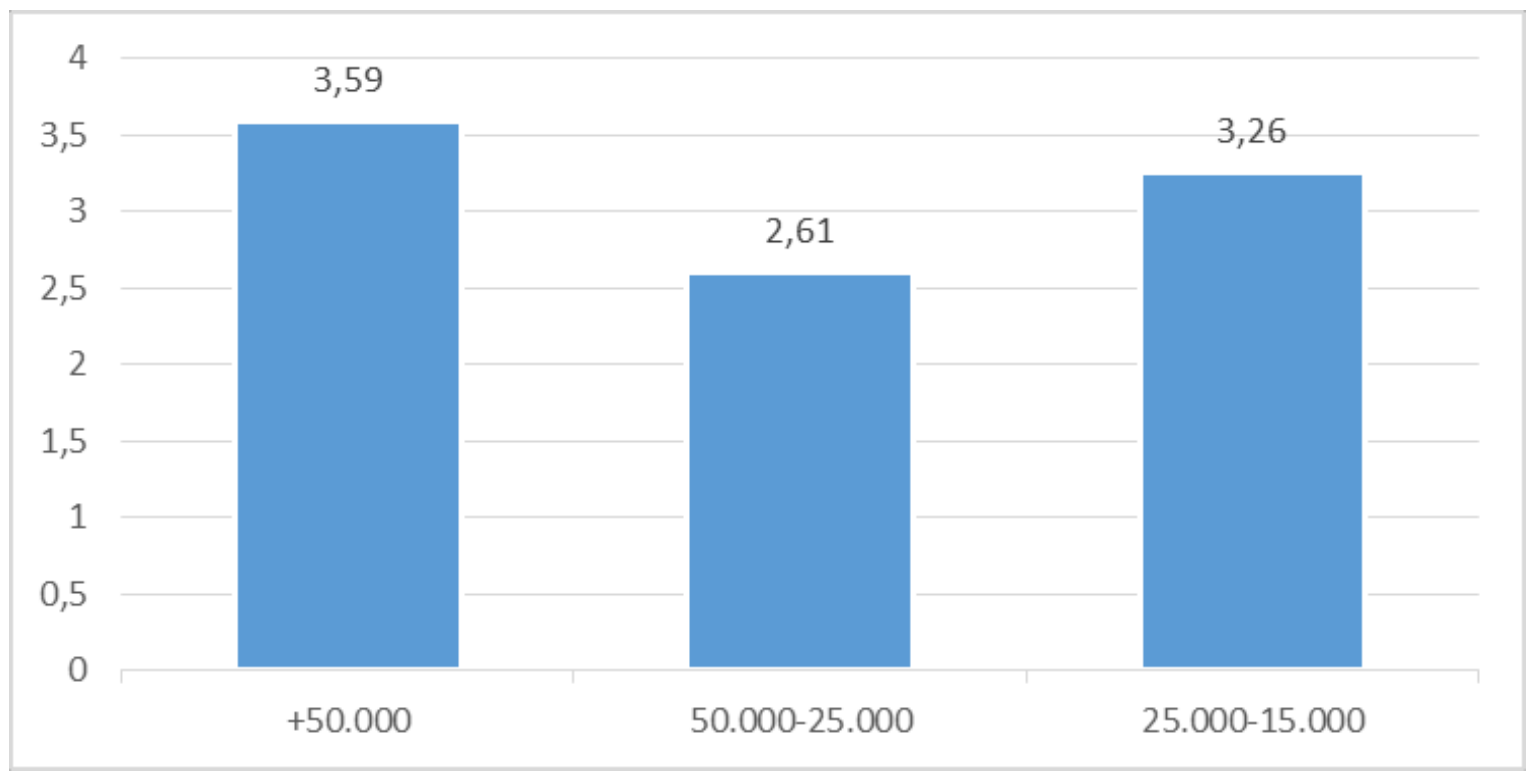

On the other hand, local governmental accountants consider more important to develop cost accounting systems than establishing a compulsory yearly external audit that at this moment is seldom practiced.

The preference for cost accounting (figure 8) can be understood by the fact that pperformance information generally entails the quantity and quality of government services and activities, or specific aspects of a transformation process, such as efficiency, or effectiveness. However, although managers and politicians usually highlight the relevance of performance information, empirical studies on performance information appreciation and use, covering a broad spectrum of countries and levels of government, shown a lack of consensus in the findings (Van Helden, 2016). Hence, performance management is a challenge confronting public serve managers (Arnaboldi et al., 2015). 
R. M. Dasí-González, A.Gimeno-Ruíz \& J. M.Vela-Bargues: The Recent Reform of Spanish Local Governmental Accounting: A Critical Perspective from Local Governmental Accountants as Internal Users of Budgeting and Financial Accounting Information

Figure 8: Cost Accounting and external audit by population

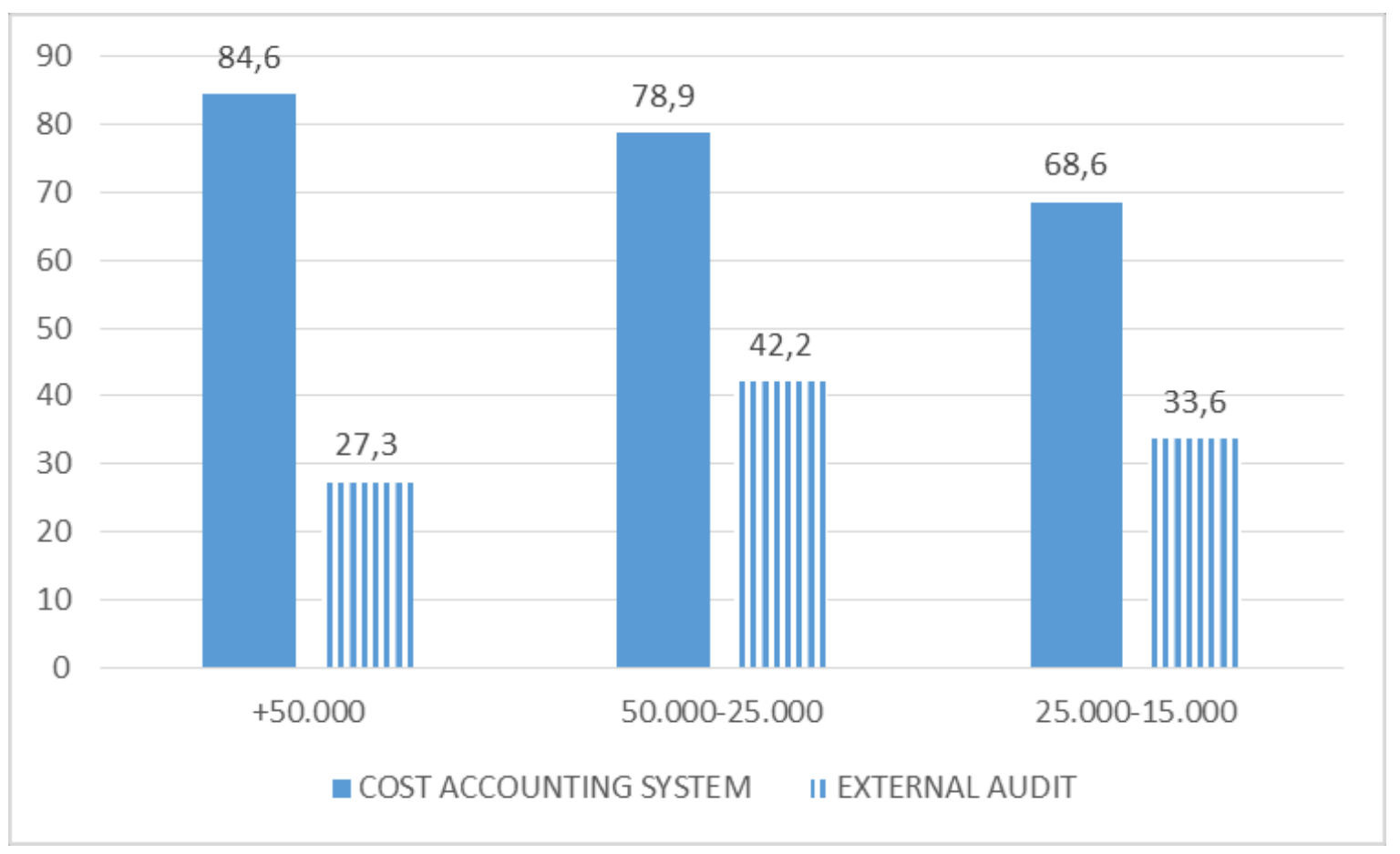

Finally, local governmental accountants that think the introduction of a compulsory external audit is appropriate, were also asked to define the criteria to determine the size of municipalities that should introduce this requirement, such as population, total amount of budget and total amount of assets. The amount of budget is chosen by $83 \%$ of accountants as the most appropriate criterion; population is selected by $55,5 \%$ and only $22,7 \%$ of respondents prefer to use the amount of assets (Figure 9). In addition, $44 \%$ of accountants considered more appropriate a combination of population and total budget amount. 
R. M. Dasí-González, A.Gimeno-Ruíz \& J. M.Vela-Bargues: The Recent Reform of Spanish Local Governmental Accounting: A Critical Perspective from Local Governmental Accountants as Internal Users of Budgeting and Financial Accounting Information

Figure 9: Criteria to establish the municipality size for requiring a compulsory external audit of annual accounts

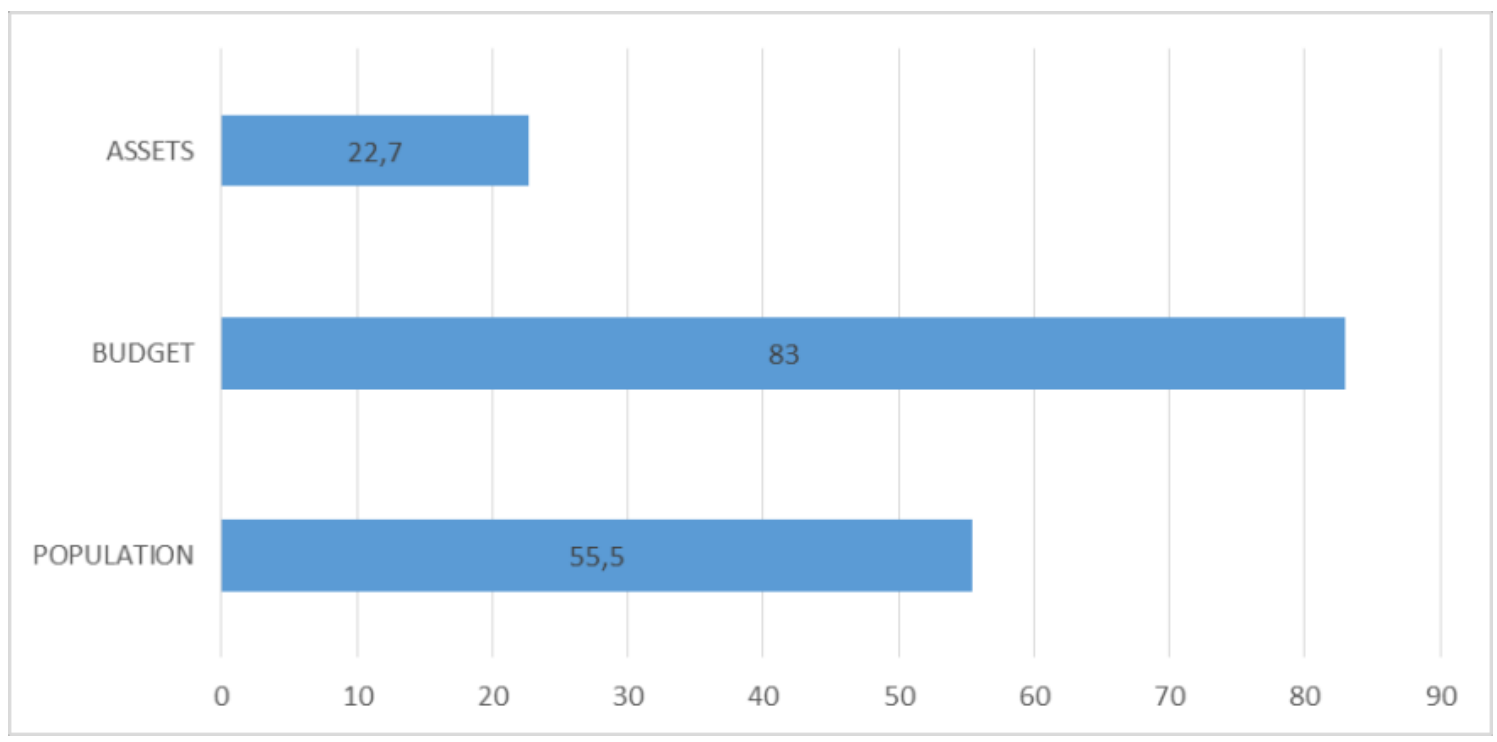

6

\section{Conclusions}

This paper aims to present the main guidelines of the recent reform of local governmental accounting in Spain, trying to identifying the main changes introduced, as well as, some key questions that are worth to analyzing

These key questions are related with the complexity and flexibility of the current accounting system, the relationship between budgetary and financial accounting information, the scope and content of financial standardized reports (annual accounts), cost accounting, consolidated financial statements, the reporting of accounting information related to national accounting figures and the external audit of annual accounts.

The paper has focused in obtaining a critical perspective of the reform from the opinions of one of the most relevant accounting information users: local governmental accountants. For that purpose, research concerned with the above key questions was implemented, developing a questionnaire that has been addressed to governmental accountants

In Spain, the accounting and reporting standards for local authorities are set by the Ministry of Economy and Finance, which has traditionally highlighted the need to introduce a financial accounting system based on accrual accounting in addition to traditional budgetary accounting system (using a modified cash basis). The Ministry of Economy and Finance has always developed this task adopting a clear paradigm: 
R. M. Dasí-González, A.Gimeno-Ruíz \& J. M.Vela-Bargues: The Recent Reform of Spanish Local Governmental Accounting: A Critical Perspective from Local Governmental Accountants as Internal Users of Budgeting and Financial Accounting Information

the superiority of accrual accounting over budgetary accounting. Under this paradigm business accounting is the model to follow when issuing governmental accounting standards.

Our analysis has found a clear gap between the aims of the reform (mainly concerned with the development of financial accounting on an accrual basis) and the opinion of local governmental accountants, who consider the system too complex and clearly biased towards financial accounting information. Local governmental accountants consider the budgetary accounting system to be more useful, and politicians have also the same opinion. We can then conclude that the paradigm of superiority of financial over budgetary accounting is a matter of fact for accounting standards setters (Ministry of Finance), but not for local governmental accountants, that are more identified with another paradigm: the superiority of budgetary over financial accounting. The gap between the expectations of accountants and standard setters is clear from an empirical point of view.

Local governmental accountants have also evidenced that the implementation of cost accounting systems can be very useful for them, even more than the presentation of consolidated annual accounts.

A final conclusion can also be drawn: local governmental accountants do not emphasize the significant value of establishing the external audit of the municipal annual accounts as compulsory. This is perhaps due to the fact that they are also in charge of internal control tasks. At this regard, the opinion of politicians, auditors, taxpayers and citizens may probably be quite different and worth to be analyzed by further research to be developed in the future.

\section{References:}

Anessi-Pessina, E., Nasi, G. \& Steccolini, I. (2010) Accounting innovations: a contingent view on Italian local governments, Journal of Public Budgeting, Accounting \& Financial Management, 22(2), pp. 250-271, https://doi.org/10.1108/JPBAFM-22-02-2010-B005.

Arnaboldi, M. \& Lapsley, I. (2009) On the implementation of accrual accounting: a study of conflict and ambiguity. European Accounting Review, 18(4), pp. 809-836, https://doi.org/10.1080/09638180903136225.

Arnaboldi, M., Lapsley, I. \& Steccolini, I. (2015) Performance management in the public sector: The ultimate challenge. Financial Accountability \& Management, 31(1), pp. 1-22, https://doi.org/10.1111/faam.12049.

Brusca, I. \& Montesinos, V. (2013) From Rhetoric to Practice: the case of Spanish local government reforms. Financial Accountability and Management, 29(4), pp. 354-377, https://di.org/10.1111/faam.12019.

Brusca, I., Montesinos, V. \& Vela, J. M. (2015) Public Sector Accounting and Auditing in Spain, In: Brusca, I., Caperchione, E., Cohen, S. \& Manes Rossi, F. (eds) Public Sector 
R. M. Dasí-González, A.Gimeno-Ruíz \& J. M.Vela-Bargues: The Recent Reform of Spanish Local Governmental Accounting: A Critical Perspective from Local Governmental Accountants as Internal Users of Budgeting and Financial

Accounting Information

Accounting and Auditing in Europe. The Challenge of Harmonization (London: Palgrave Macmillan), pp.173-188.

Dasí, R. \& Gimeno, A. (2014) Financiación Básica. Especial referencia a las subvenciones y Patrimonio Neto, In: Bargues, V. (ed) La nueva contabilidad de la Administración Local: una aproximación normativa, práctica y conceptual (Valencia, Spain: Universidad Politècnica de València. Diputación Provincial de Valencia), , pp.189-211.

Ellwood, S. (2001) Accruals accounting approaches in the UK public sector: diversity and convergence, In: Bac, A. D. (ed) International comparative issues in government accounting (US: Springer), pp. 213-232.

Fuertes, I. \& Vela, J. M. (2000) La contabilidad de la Administración Local en Europa. Revista Española de Financiación y Contabilidad, 29(105), pp.657-686.

Grossi, G. \& Tagesson, T. (2008) Consolidated financial reports in local governments- a comparative analysis of IPSAS and SCMA, In: Jorge, S. (ed) Implementing reforms in public sector accounting (Coimbra: Universidade de Coimbra/Coimbra University Press), pp. 337-349.

Grossi, G., Mori, E. \& Bardelli, F. (2014) From Consolidation to Segment Reporting in Local Government: Accountability Needs, Accounting Standards, and the Effect on DecisionMakers, Journal of Modern Accounting and Auditing, 10(1), pp. 32-46.

IFAC (International Federation of Accountants) (2012) Reporting on the Long-Term Sustainability of a Public Sector Entity's Finances (New York: IFAC).

IFAC (International Federation of Accountants) (2014) Handbook of International Public Sector Accounting Pronouncements (New York: IFAC).

Montesinos, V. \& Brusca, I. (2008) Whole of government financial reporting: Fashion or necessity, Workshop on whole of government financial reporting: International trends, Siena, Italy.

Montesinos, V. \& Vela, J.M. (2003) Spain, In: Lüder K. \& Jones, R. (eds) Reforming governmental accounting and budgeting in Europe (Frankfurt, Germany: Price Waterhouse Coopers), pp. 671-753.

Montesinos, V., Vela, J. M. \& Benito, B. (2001) Accounting and Financial Reporting in Spanish Regional Governments: Exploring Similarities and Differences, In: Bac, A. (ed) International Comparative Issues in Government Accounting (Springer: US), pp. 195-212.

Navarro-Galera, A., Rodríguez-Bolívar, M. P., Alcaide-Muñoz, L. \& López-Subires, M. D. (2016) Measuring the financial sustainability and its influential factors in local governments, Applied Economics, 48(41), pp. 3961-3975, https://doi.org/10.1080/00036846.2016.1148260.

OECD/IFAC (2017) Accrual Practices and Reform Experiences in OECD Countries (Paris: OECD publishing), https://doi.org/10.1787/97892642270572-en.

Pina, V., Torres, L. \& Yetano, A. (2009) Accrual Accounting in EU Local Governments: One Method, Several Approaches, European Accounting Review, 18(4), pp. 765-807, https://doi.org/10.1080/09638180903118694.

Tagesson, T. (2009) Arguments for proportional consolidation: The case of the Swedish local government, Public Money and Management, 29(4), pp. 215-216.

Van Helden, J. (2016) Literature review and challenging research agenda on politicians' use of accounting information, Public Money and Management, 36(7), pp. 531-538, https://doi.org/10.1080/09540962.2016.1237162. 
LEX LOCALIS - JOURNAL OF LOCAL SELF-GOVERNMENT

R. M. Dasí-González, A.Gimeno-Ruíz \& J. M.Vela-Bargues: The Recent Reform of Spanish Local Governmental Accounting: A Critical Perspective from Local Governmental Accountants as Internal Users of Budgeting and Financial Accounting Information

Vela, J. M. (1996) Latest Developments on Local Government Accounting in Spain, Financial Accountability and Management, 12(3), pp.205-224, https://doi.org/10.1111/j.1468-0408.1996.tb00423.x

Vela, J. M. (2014) La normalización de la Contabilidad de la Administración Local, In: Vela Bargues, J. M. (ed) La nueva contabilidad de la Administración Local: una aproximación normativa, práctica y conceptual (Valencia: Universitat Politècnica de València. Diputación Provincial de Valencia).

Vela, J. M. (2015) La normalización de la Contabilidad Pública española: una visión crítica tras cuatro décadas de reformas (Valencia: Real Academia de Cultura Valenciana). 